THEATRE RESEARCH INTERNATIONAL $\cdot$ VOL. $26 \mid$ no. $3 \mid p p 285-293$

(C) International Federation for Theatre Research 2001 . Printed in the United Kingdom

\title{
Building Bridges: Life on Dunbar's Arbor, Past and Present
}

\author{
ELAINE ASTON AND JANELLE REINELT
}

Rita, Sue and Bob Too by Andrea Dunbar and A State Affair, by Robin Soans. Co-production Out of Joint, Liverpool Everyman and Playhouse, and Soho Theatre Company. Double bill first performed at Liverpool Everyman on 19 October 2000 and Soho Theatre, London on 5 December 2000.

Andrea Dunbar wrote her first play The Arbor when she was fifteen and still at school. It was staged some two years later at the Royal Court's Young Writers Festival and, in an expanded version, transferred from the studio theatre Upstairs to the main house, Downstairs. The Arbor was drawn directly from Dunbar's experiences - of abuse, violence, and a teenage pregnancy. Autobiographical, authentic and working-class were characteristics reviewers regularly attributed to her work. During her short lifetime (born in 1961, she died of a brain haemorrhage at the age of twenty-nine), her canon of three plays - The Arbor (1980), Rita, Sue and Bob Too (1982) and Shirley (1986) - formed a dramatic focus for the brutality of working-class lives in 1980 os Britain. More specifically, Dunbar's theatre gave a presence to the working-class lives of girls and women, as she knew and experienced them from life on the Buttershaw Estate, Bradford.

The second of her plays, Rita, Sue and Bob Too, was performed within two months of Caryl Churchill's Top Girls. ${ }^{1}$ While Churchill prophesied a 'frightening' future for young working-class women, Dunbar's play provided a stark look at the dead-end lives of two working-class girls already being lived. Rita and Sue, about to finish school without any prospects of a job, have underage sex with Bob, the husband of the family for whom they baby-sit. After a series of sexual encounters, mostly managed in Bob's car, Rita becomes pregnant. Bob leaves his wife, Michelle, and sets up house with Rita. Sue leaves school and also home when she finds herself a boyfriend. Any feminist tendencies in Dunbar's work were not the result of middle-class theorizing (which we are certain she would have scorned), but the effect of telling life as it is: of showing a working-class community of men and women ravaged by the social policies of Margaret Thatcher's government, but in which women fared worst as a result of male violence, abuse and alcoholism.

In reviving Rita, Sue and Bob Too for 2000-1, Max Stafford-Clark, director of the 1982 production, returned to the play with a renewed concern for working-class lives. His initial idea was to stage a trilogy, charting changes to working-class lives and the rise of what politicians now commonly refer to as Britain's 'underclass'. The trilogy would start with D. H. Lawrence's The Daughter-in-Law, followed by Rita, Sue and Bob Too, and then a third, 
more recent play. $^{2}$ When Stafford-Clark could not find the third play ready-made, plans were modified: Rita, Sue and Bob Too would join a new play, A State Affair, researched and workshopped by Stafford-Clark's company Out of Joint, along similar lines to the working methods of his former company, Joint Stock. Stafford-Clark's current policy for Out of Joint is to stage a classic drama with a linked piece of new writing in the interests of mutual interrogation or illumination. In pairing Dunbar's original play with the new 'documentary' drama based on the estate where Dunbar lived, he found a way of highlighting the deterioration of lives on Britain's estates in the eighteen years since the 1982 première of Dunbar's play.

Rita, Sue, and Bob Too and A State Affair were staged at the Soho Theatre, one of the new venues made possible through National Lottery funds for theatre buildings, ${ }^{3}$ now permanent home to the thirty-year old Soho Theatre Company, dedicated to new writing, and a co-producer of the double bill. Max Stafford-Clark wanted middle-class audiences to see this show, ${ }^{4}$ and nowhere seemed better than this new venue tucked in between the restaurants and clubs of Soho. Both upscale and still seedy, Soho has a history and association with strip-shows, drugs and youth culture, but more in evidence now are 'tasteful restaurants' and chic shops. However, Soho still remains a crossroads of artistic and bohemian life, especially for twenty-something white-collar workers. The striking thing about the spectators for Stafford-Clark's production was that they were young, fashionable, and/but deeply engaged by the evening. Coming in from the bar with drinks to the first act, they were noisy and ebullient, laughing hard at the first-act sex jokes, and Bob's naked buttocks going up and down in the opening sex-in-the-car scenes, but as the play(s) developed, the audience became quieter, more attentive and responsive to the social picture. While their 'horizon of expectation' may have been coloured by the upbeat film of Rita, Sue and Bob Too (1987), or the possibility of another 'lads-and-drugs play' (in the manner of Irvine Welsh's 1996 Trainspotting), spectators, instead, had to engage with a stark, chilling treatment of poverty and drugs which, while entertaining, ultimately was designed to provoke. As writer Robin Soans argued, he wanted his play to 'make people think, and absorb them to a degree that the first thing they think of when the lights go down isn't: 'Will I have a gin and tonic or a red wine?'5 Audience reactions at the Soho Theatre suggested that the production certainly succeeded on those terms.

Urban decay and decline were visually encoded in Es Devlin's design which used the same touring set for both plays. Working with a minimalist aesthetic, and in keeping with the stark, spartan style of the original, which had been labelled 'new brutalism', the overall effect was one of abject poverty; dead-end lives, with nowhere to go. A strip of wasteground ran across the back of the stage, 'walled' in by an ugly concrete-styled surround, studded with television monitors: depending on your perspective, you either felt as if you were watching the performance played out in the back of a television set, or, as though you might be looking down from the height of a tower block to a strip of waste ground below.

Through its scenographic use of television monitors (ten in all) the production engaged in the ongoing debate in theatre studies about the relative merits and differences between live and mediated performances. Although the material of the plays is drawn from 'real life', and although the performance style of the first play is a kind of realism, the presence of the monitors seemed to mark the interpenetration of media into real life and

\section{CAMBrIDGE JDURNALS}


private experience, constantly reminding us that a new subjectivity is created in relation to the constant recourse to television. As Philip Auslander has argued, live performance 'cannot be shown to be economically independent of, immune from contamination by, and ontologically different from mediatized forms ${ }^{6}{ }^{6}$ Thus the monitors created a kind of metacommentary, referring not only to the lives of the characters inside the play, but also to the viewing apparatus of the spectators of live theatre.

The monotonous and deadening impact of television in Rita, Sue and Bob Too was clear from the way in which the screens only occasionally moved into colour and/or images, were more often blank, or, as in scene two, as a reminder of a time before virtual 24-hour programming, showed the old BBC testcard (synonymous with boredom). ${ }^{7}$ One exception to this effect was the staging of scene six where the girls bunk off school to meet up with Bob and drive out to some fields for a 'jump'. During the drive (all mimed) Bob lectured the girls (in teacherly discourse) on Thatcher, unemployment and their dead-end futures. Getting out of the confined space of the car and into the fields, however, brought with it a sense of release from their impoverished lives. The image of them lying down, bathed in green light, with the monitors showing tree-tops and sky, momentarily contrasted with the urban scenes. But this was no idyllic image of the English countryside, with the promise of a life that will get better. The field is full of 'cow shit'. As she steps in it, Rita comments: 'that's a fresh dollop of shit. Look at the flies on it. The next you know they'll be in your house walking over your tea. ${ }^{8}$ And the feeling of temporary respite was confirmed by the big showdown that followed, as the relationship between Bob and the girls is discovered. The television monitors switched to watching, spying neighbours, behind their net curtains, as the girls and their families hurled violent abuse and accusations at each other. Watching the watching neighbours was a reminder to the audience of popular fly-on-the-wall television viewing, except here such viewing was 'alienated' rather than voyeuristic.

That the feeling of entrapment and dead-end lives is also gendered, or, rather, in Dunbar's view, was worse for women than for men, was staged through the motif of the ironing board in Rita, Sue and Bob Too. Scene three dramatizes the girls taking off their clothes for Rita to iron them; Sue explains there is no iron in her house, and they have to borrow next door's iron if they want to iron at all. And in scene nine, Rita, pregnant and preparing to leave home, 'replaces' the figure of Michelle (seen ironing children's clothes in scene five) and becomes the 'wife'. In the production, Rita, in a pink Minnie Mouse nightshirt (which underlined how much of a child she still is) stood at the ironing board - a representation of the unchanging cycle of women's lives. It was impossible not to see echoes of the Court's Look Back in Anger when the ironing board made its appearance. But Dunbar's girls (and women) are differently positioned to Osborne's middle-class Alison within his misogynist framing. By contrast, her young women will fight for whatever they can in the face of acute social deprivation, and without lamentation for lost causes, or lives desired to be lived differently.

While Dunbar shaped Rita, Sue and Bob Too out of the lives of three families, A State Affair has no family life to speak of. Families and communities have been damaged and ripped apart through deprivation, abuse and drugs. Robin Soans explains how after 'deindustrialization', 'all the traditional facets ... around which a community might cohere' disappeared. 'Not only did the factories shut down', Soans observes, 'but the

\section{CAMBRIDGE JDURNALS}


swimming pool and the hairdressers and the corner shop and the post office, all the places that might create a feeling of community, also went. Then, at the height of people's frustration, that's when heroin hit, and it had a fantastically damaging effect.'

The 'fantastically damaging effect' of heroin, unemployment and lack of community structures are recorded in A State Affair through a dramaturgical shift from Dunbar's style of realism (the play has no act or scene arrangements) to a continuous, multi-vocal, multinarrativizing of individual lives from the Buttershaw Estate which, threaded together, tell an overarching tale of abuse, domestic violence, drugs and crime. The two plays require two different performance registers, and in fact, the impact of the evening depended on the contrast between the first and second halves, not only in terms of changes between the $1980 \mathrm{os}$ and 2000 on the Bradford estates, but also in terms of changes of representational style. Dunbar was working with a kind of realism which depended on convincing psychological portraiture. As an ensemble, the Out of Joint company worked collectively and individually towards rhythms and registers that would authenticate life on the Buttershaw estate; Bradford at the start of the 1980 s, watched by an audience at the beginning of a new century. The performances were variously described as 'hard, sensitive and accurate, selfless', ${ }^{10}$ or delivered with 'splendidly unobtrusive skill'. ${ }^{11}$ But the language of journalism has not kept up with the critique of realism which a discussion of this piece requires in 2000 . What, after all, do the words 'accurate' and 'selfless' really mean in terms of acting choices if, as we noted earlier, all experience is mediated through television and other cultural performances? Rather, the actors created a style that respected the experiences on which the text was based, but which was carefully crafted to be just that - a style.

The overall performance technique aimed at matching the aesthetic of the set design: hard-edged, and with an emotional impact which came not from the conventional, heartwrenching style attendant on certain forms of classic realism, but from the dead-pan, downto-earth mode of understatement, or way of 'telling-it-as-it is' register. Within this overall, shared register, individual performers picked out different styles of delivery for their specific characters. Emma Rydal's performance as Sue reflected Dunbar's own attitude and behaviours. Interestingly, this biographical connection carries forward into A State Affair, as Rydal took the role of Dunbar's daughter, Lorraine. Max Stafford-Clark reflects on what he learnt after meeting Andrea Dunbar and the way in which she never allowed herself to show how she felt about things one way or another: 'It was a culture where you didn't give yourself away. Admitting to pain or showing enthusiasm were equally undesirable. You had to be hard. And Dunbar had developed stoicism and stubbornness that were impermeable and particular' (Programme, p. 2). The performance of Sue worked with the concept of not giving yourself away - holding feelings in, appearing non-committal about the sexual pleasure with Bob, and so on. (See Figure 1 for an imaging of Rydal's self-contained body language, arms folded and hard stare, resistant to the hostility and tensions from Mum and Dad.) In this way, she contrasted with the relatively ebullient Rita (played by Emily Aston), whose more open, childlike way of being in the world was intertwined with the girl already figured as woman. While on the one hand, these differences set up a certain dissonance between characters, denying a unified psychological realism, and making each character seem like a quotation, the style crafted is not so far from familiar representations as to be actually 'alienated'. It is quite possible to think of the characters as 'real people', to identify,

\section{CAMBRIDGE JDURNALS}




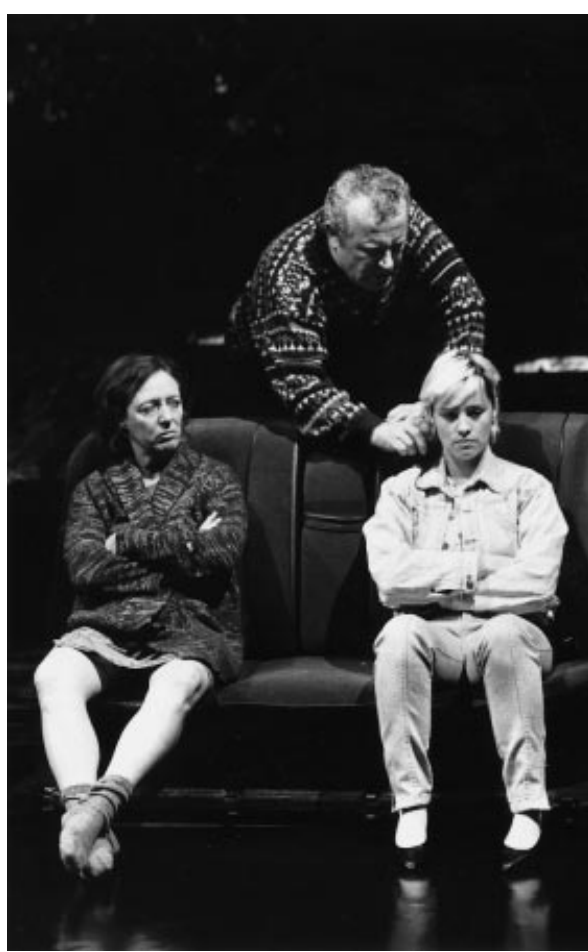

FIG. 1 Jane Wood as Mum, Ian Redford as Dad, and Emma Rydal as Sue, in Rita, Sue and Bob Too. Photograph courtesy of the Soho Theatre \& Writers' Centre, London. (Photo: John Haynes)

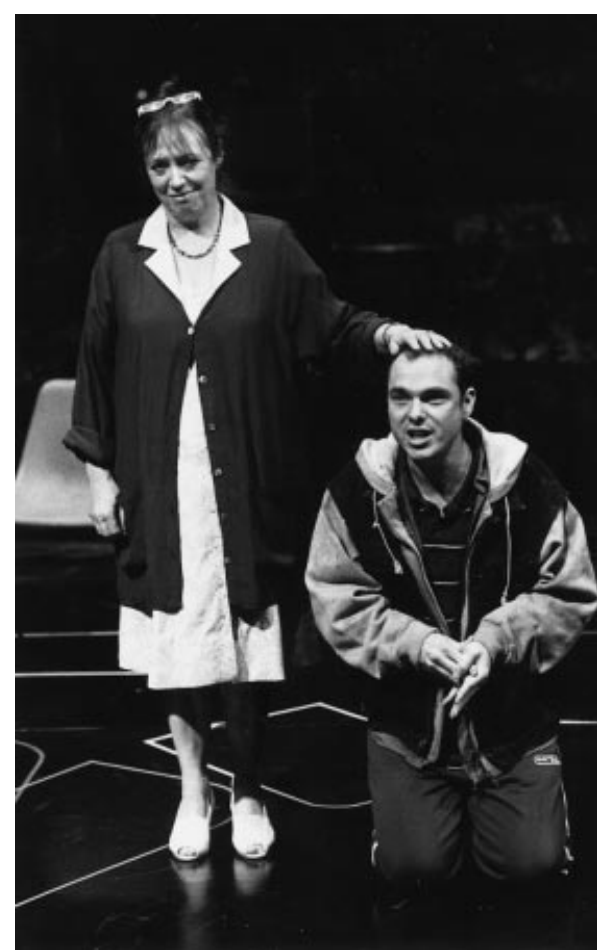

FIG. 2 Jane Wood as Sue, and Gary Whitaker as Dean, in A State Affair. Photograph courtesy of the Soho Theatre \& Writers' Centre, London. (Photo: John Haynes)

suspend disbelief, and in other ways naturalize the performances. The television monitors seem at times to be mocking this kind of reception, and the slight incongruity of the performance styles supported this janus-faced representation.

It would still have been possible to simply receive the representations in Rita, Sue and Bob Too through the rubric of an unexamined realism, (indeed, the rhetoric of the journalists certainly fell into that trap), if it were not for the juxtapositions of the second play. In effect, the second play sends the audience back to the first to view it in retrospect as a slightly sentimental product of its historical time (Stafford-Clark suggests 'folkloric'), ${ }^{12}$ or at least innocent in its presuppositions, not only in terms of the content of its representation, but also in terms of its apparatus. The production seemed to want an audience to recognize the impossibility of transparency, that all representations are to some extent mediatized ones, at the same time arguing that the 'gist', spirit, or even 'truth' of the milieu can be respected and theatricalized, if not mimetically copied. Among the features of life on the estates performed were, for example, the rawness of lives going nowhere, especially the broken edges of the relationship between Mum and Dad; the rhythm of frustration of pleasures, countered by the desperation of taking whatever pleasures might come your way (seen graphically in Bob's actions). Perhaps exceptional in this context was Sally Rogers's performance as

\section{CAMBridge JDURNALS}


Michelle, a character who figures as an older version of Sue: a woman desperate to remain self-contained, and to hide her feelings in the face of her faithless husband. But the effort proves too much. The playing of this character switched between a performance of control (Rogers worked in an over-slow physical and vocal rhythm in an attempt to stay calm) and violent outbreaks of repressed anger and disappointment. The cacophony of raised voices and physical threats in scene eight, as the families quarrel, showed the violence and frustration erupting out of all of these lives. But the moments of high-energy exchanges between the girls, or within and/or across families do not bring about social change. The final pub scene makes this clear. You take what bits of 'comfort' or 'pleasure' you can, but the possibility of major, socially progressive change is not in view.

A State Affair breaks with this circumscribed realism (circumscribed because its claims to truth are qualified through the acknowledgement of the always mediated and modified nature of performances) to work in a style Stafford-Clark has called 'verbatim theatre'. The play is 'documentary' in the sense that it is based on documents - the interviews from the Buttershaw Estate. It seems, therefore, to be trying to go beyond the constructed realism of the first play, to be more accurate or authentic or real. This would be a partially mistaken perception, however. It is rather a matter of a different mode of theatrical discourse. Stafford-Clark describes verbatim theatre in some of the old language: 'To represent the research as accurately as possible. . . It involves sound research and journalistic skills as well as a belief that authenticity is inherently dramatic' (Programme, endnotes). We can note his recognition that the theatre will always be at one remove from the original; it is an accurate representation that is desired, but 'as accurately as possible' implies it will not be completely possible to be completely accurate. He also claims a link between authenticity and the dramatic. This might be seen as the desire for transparency, but it can also be read (at least by theatre scholars) to be a claim for the authenticity of the dramatic, that performance makes its own claims of authenticity, different ones from lived everyday life. Philip Rosen, writing in Theorizing Documentary, connects documentary representation with historiography through 'the indexical traces of the presence of a real past' in both documentaries and in historiography. ${ }^{13}$ The verbatim words of the interviewees form the trace of the past, the index, through the actors' bodies and words, of the presence of the trace of the reality for which they stand. This is a pretty strong truth claim in a postmodern age.

The other striking feature of the performance style for A State Affair is direct address. To the tune of Moby's 'Why does my heart feel so bad?', the performers began by assembling on stage and engaging the spectators with their stories. The drab, graffiti, concrete-like surface of the set was still there as backdrop, but now the actors/characters strained forward, maybe looking for ways out? The stories were for us, the spectators, to hear; the performers had little interaction with each other, thereby emphasizing the role of the spectator as listener. Stafford-Clark explains this as a function of accurately representing the research, but it also activates a different kind of relationship to the audience than in the first play. Watching from outside, the audience could still choose to see Rita, Sue and Bob Too at arm's length; but the dialogue moves to include the audience when the form of dialogue changes to direct address. Similar to the Brechtian effect of the juxtaposition of the first and subsequent scenes of Top Girls, this change of convention breaks the boundaries of the first play's contract with the audience, and invokes the ethical dimension of face-to-face address.

\section{CAMBrIDGE JDURNALS}


Even though the audience does not literally 'speak back', they become active listeners. Performer Emily Aston, talking about conducting the interviews with the Buttershaw residents, found herself 'doing a lot of listening' (Programme, endnotes). Another theatrical artist who uses verbatim interviews is Anna Deavere Smith. Although in Smith's case she performs all the interviews through solo work, playing all the parts, her project is strikingly similar to Stafford-Clark's in its desire to display the relationship between listening and speaking as the essential part of the performance: '[The spirit of the theatre] lies in the bridge that makes unlikely aspects seem connected. The bridge doesn't make them the same, it merely displays how two unlikely aspects are related. ${ }^{14}$ This bridge can be built in performance in different ways. A State Affair uses direct address as its main form of bridgebuilding, while another trace of the presence of the past (and another kind of bridge) appears in the 'character' of Andrea Dunbar's daughter. Talking to the audience about her own experiences, including her anger at her mother for wanting to abort her, she also makes an intervention into the bridging activity of the play. She talks both about how the first play would have been different if her mother wrote it today, and also about what she herself would write: 'If I wrote a play, I'd do it about the Buttershaw Estate. It'd show some people getting their lives together with a lot of courage and determination. But it would also show others going down a big steep hill, into a big black hole' (Programme, p. 134). In fact, this is more or less what $A$ State Affair does.

With respect to showing 'some people getting their lives together', A State Affair introduces the setting of Agape House. In real life, Agape House is a care centre. In the play, it stands as a composite of various different places where help is being given to the 'underclass', and in that sense is admittedly mythical. When Agape House was first mentioned in the production it was accompanied by a change in the performance rhythm: a quickening of tempo, in keeping with a more optimistic note. However, even though it seems a bit like an oasis in the sea of despair, it is carefully marked with specificity and noted for its only limited effectiveness. While based on strict Christian doctrines of love and redemption, Agape House is clearly not for everybody. It has its own excluded. Sue, the woman running Agape House (see Figure 2 for a visual encoding of her devotee image; her hand, in religious-styled blessing, resting on the head of heroine addict, Dean), speaks disparagingly of Asians, and explicitly says, 'Two gay guys allowed to adopt more children . . . how sick is this world getting? How's your mummy? I've just got two dads. I could get really angry. When it comes to children and things, I could get really passionate' (Programme, p. 130). This might be a direct quotation from a right-wing commentator such as Charles Murray, who advocates the abolition of the welfare state (see Programme, p. 9). So what are we to make of this? First, it undoubtedly comes out of interviews, so it is the trace of the true-real. Stafford-Clark made a decision to include it - why might he have done that? We think it might be because Agape House must be noted with its limitations and specific character in order to stand in for actual places that exist. In the same way that the drug addicts who live there are depicted as still using, as constantly on the edge of going under, the thinking and world view of the actual people who work with the addicts trying to help them must be depicted too.

Agape House is no panacea. Not only does it lack resources, hours in the day, and space to ameliorate the situation in the Estate, it also is not utopian in its precepts and

\section{CAMBrIDGE JDURNALS}


ideology. This subject touches on the ultimate question about the production as a whole: does it offer any hope, or any programme for change? This is a difficult question because the historical trajectory of the narrative is downhill. In the 1980s there was poverty and abuse on the Buttershaw Estate, but not heroin and crack in the quantity that exists today, with the brutality and disease which accompany those drugs. In addition, the crushing economic conditions of recession and the social services dismantled in the Thatcher years have not been matched in recovery, even if, as Stafford-Clark notes, thirty one million pounds has been spent renewing the Estate (Programme, endnotes).

If there are no answers or programmes for clear action in the production, it is not true that there is only despair. The odd figure of the cast performing t'ai chi at the end of the show brings a kind of formal closure, but it has also had a more precise articulation earlier when Paul tells about learning it in Doncaster Prison: 'If you were off the gear, you went down to the yard and did t'ai chi ... a group of us in the courtyard standing on one leg. There were all sorts - addicts, grafters, a couple of lifers ... balanced on one leg. T'ai chi puts you to sleep, so it helps with the rattling ... helps you relax ... helps you sleep at night' (Programme, p. 105). The image of the group on stage doing t'ai chi makes for an image of solidarity and connection across difference (especially since the characters speak only to the audience), and so part of a vision of hope is this connection or bridging between the characters; however, t'ai chi is also something actors do as part of their training. In the image, the production's theatricality and the identity of the actors rather than the characters is also figured. Part of the feeling of hope comes from the energy of the performance event, its artistic effort as an intervention into reality. In Performing History, Freddie Rokem notes that theatre itself enters into the dialectic of history's failure and the future's possibilities: 'what may be seen as specific to the theatre ... is its ability to create an awareness of the complex interaction between the destructiveness and the failures of history, on the one hand, and the efforts to create a viable and meaningful work of art, trying to confront these painful failures, on the other. ${ }^{15}$ Within the context of the difficult situation of the present, this theatrical mediation between past and future carries its own energy of hope.

NOTES

Top Girls was first performed on 28 August 1982. Rita, Sue and Bob Too premièred on 14 October 1982.

2 For further details see Max Stafford-Clark and Robin Soans in interview with Brian Logan, Time Out, 29 November-6 December 2000, pp. 28-9.

3 One hundred and fifty two million pounds invested by September 1999. Cited in 'Roles and Functions of the English Regional Producing Theatres', Final Report to the Arts Council of England, Peter Boyden Associates, May 2000, p. 11.

4 In the Time Out interview (see note 2), Stafford-Clark states: 'I think they're the people [middle-class audiences] who need the information about that world'.

Interview, Time Out.

Philip Auslander, Liveness (London and New York: Routledge, 1999), p. 7. In A State Affair the sets mostly imaged the 'snow' effect of a television that is not properly tuned in. Rita, Sue and Bob Too (London: Methuen, 200o), p. 53. This volume also contains Robin Soans's $A$ State Affair, several commentaries by production members, as well as research materials. The publication was used as the programme for the production. Further citation from this volume is referenced in the text as 'Programme'.

\section{CAMBRIDGE JDURNALS}


Interview, Time Out, p. 28.

John Peter, Sunday Times, Culture Section, 12 November 2000.

Paul Taylor, Independent, 6 December 2000.

Interview, Time Out, p. 28.

13 Philip Rosen, 'Document and Documentary: On the Persistence of Historical Concepts in Theorizing Documentary', in Michael Renov, ed., Theorizing Documentary (London and New York: Routledge, 1993), p. 65.

14 Anna Deavere Smith, Fires in the Mirror, (New York: Anchor Books, 1993), p. xxix.

15 Freddie Rokem, Performing History; Theatrical Representations of the Past in Contemporary Theatre (Iowa City: University of Iowa Press, 2000), p. 3.

ELAIN A A TON is Professor of Contemporary Performance at Lancaster University, UK, where she teaches courses in performance analysis, theatre practice, and contemporary feminist theatre. She is author of Feminist Theatre Practice (Routledge, 1999), Caryl Churchill (British Council, 1997, second edition, 2001) and co-author of Theatre As Sign-System (Routledge, 1991). With Janelle Reinelt she has co-edited The Cambridge Companion to Modern British Women Playwrights (Cambridge University Press, 200o).

JANELLE REINELT is Associate Dean in the School of the Arts at University of California Irvine, and Vice President for Publications of IFTR/FIRT. Her books include After Brecht: British Epic Theatre (1994), Crucibles of Crisis (1996), Critical Theory and Performance with Joseph Roach (1994), all published by the University of Michigan Press, and she is the co-editor of The Cambridge Companion to Modern British Women Playwrights (Cambridge University Press, 2000) with Elaine Aston.

\section{CAMBridge JDURNALS}

